\title{
Application of Modelling Building Information Modelling (BIM) in Bagendang Port Multipurpose Extension at Central Kalimantan
}

\author{
Yoni Galieh Kinanda ${ }^{1}$, Ronny Durrotun Nasihien ${ }^{2}$ \\ Narotama University, Surabaya \\ yoni.galieh@gmail.com
}

\begin{abstract}
BIM is a technology in the field of AEC that is able to simulate all information in a development project into a 3-dimensional model. In the world of construction in Indonesia BIM technology is still very minimal applied to the world of construction. he purpose of this final project is to design a planning model for the Extension of the Bagendang Port Multipurpose Pier in Sampit, Central Kalimantan using software from Aecosim. The results of this study show 3D results from the modeling of the Pier structure. This shows that BIMbased applications in planning and designing a building model can simplify the design analysis process.
\end{abstract}

Key Word: Building Information Modeling, architecture, structure analysis, volume, building design.

\section{INTRODUCTION}

In connection with the development of PT Pelabuhan Indonesia III (Persero) in Bagendang Port, Central Kalimantan, as an effort to improve port facilities along with the increase in container traffichence planning is needed in the field of Dock Extensions in Bagendang Port.

Considering the need for a planned Extension of the Pier in Bagendang Port, the preparation and manufacture of DEDs is required. The DED preparation (Detail Engineering Design) of the work in question is the work of the Multipurpose Pier Extension in Bagendang Port.

\section{LOCATION}

The location of the planned Bagendang Port Pier Extension is in Central Kalimantan.

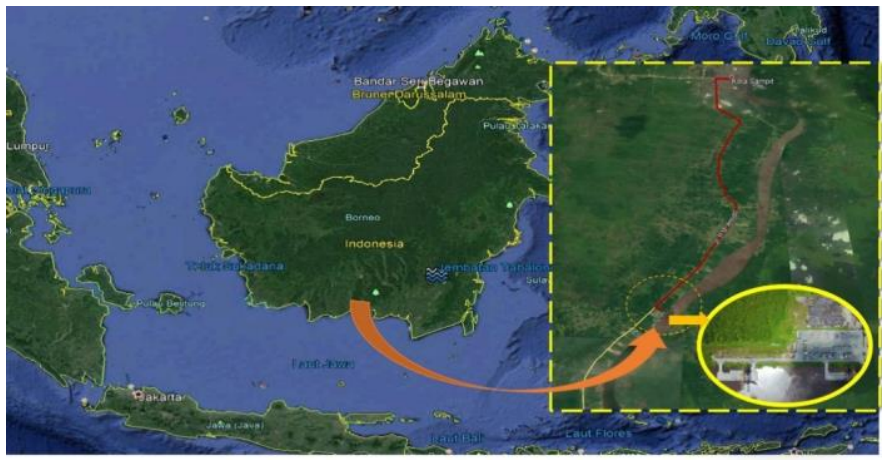

Figure 1Location of Bagendang Pier Extension Planning.

Building Information Modelling (BIM) in Bagendang Port Multipurpose Extension at Central Kalimantan Yoni Galieh Kinanda, Ronny Durrotun Nasihien 


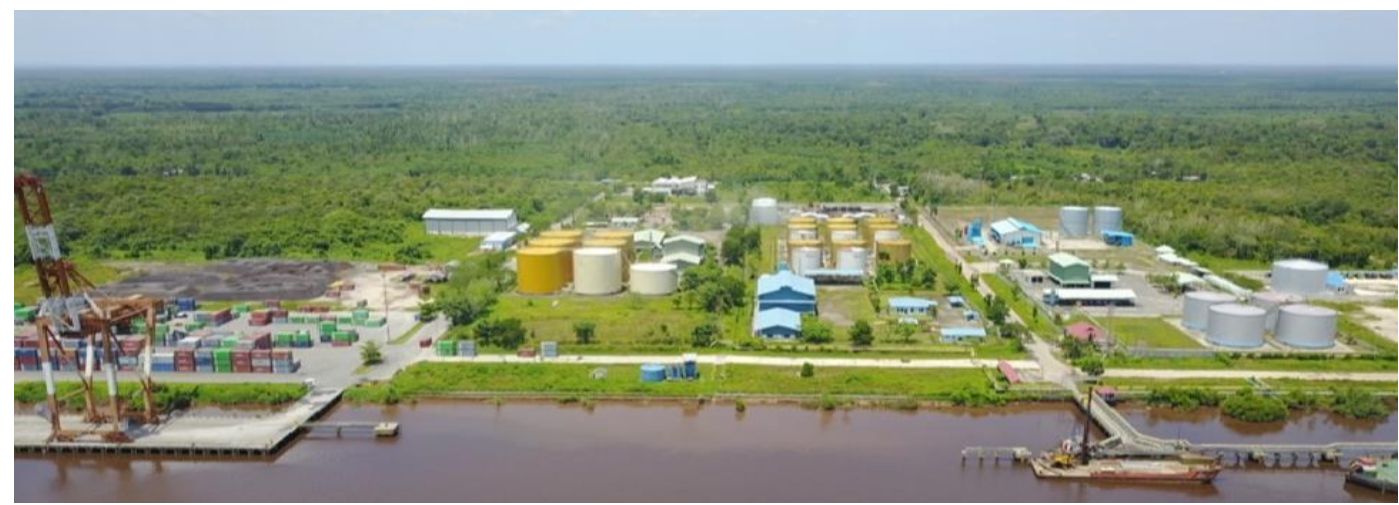

Figure 2Existing Conditions of Bagendang Port Multipurpose Pier.

\section{LITERATURE REVIEW}

\section{Building Information Modeling}

Building Information Modeling (BIM) is a process in producing and managing data of a building during its life cycle. BIM uses 3D software, real-time, and dynamic building modeling to increase productivity in building design and construction. The BIM production process includes building geometry, space relations, geographical information, and the quantity and quality of building components

BIM can be used to show all building life cycles including the process of construction and operation of facilities. The quantity and quality of a material can be easily extracted. The scope of work can be divided, separated and determined. Systems, installations and sequence sequences can be displayed on a scale relative to all facilities or groups of facilities. BIM wants changes in the stages of traditional architecture and more data share than what architects and engineers generally use. BIM can be used to achieve progress with model drawings of the actual parts used to build a building.

The term Building Information Model is basically the same as the Building Product Model, which has been widely used by Professor Eastman in his books and papers since the late 1970s.

\section{Pier Planning Evaluation}

\section{METHOD}

In planning the Extension of the Multipurpose Pier in Bagendang Port, this includes planning the type of pier, the length and width of the pier, floor plate and pier beam and pile foundation

\section{Construction Drawings.}

The construction of this construction image has the purpose of facilitating the implementation of the construction of the port and dock in the project location. Construction drawings must be made as well as possible and correct according to the dimensions, size and shape of the building and the planned location so that it can be easily understood by the person / agency that will build the project.

\section{BIM modeling}

After the data collection stage the next step is to input and apply the data in the Model Building Information Modeling using Aecosim software. The output produced is a modeling structure both $2 \mathrm{D}$ and 3D. These results will certainly greatly assist the implementation of the project later and it is expected that the data delivered to the implementers will be easy to understand and minimize the occurrence of different points of view in making construction decisions..

\section{ANALYSIS \& DISCUSSION}

Building Information Modelling (BIM) in Bagendang Port Multipurpose Extension at Central Kalimantan Yoni Galieh Kinanda, Ronny Durrotun Nasihien 
In this study using the Multipurpose Pier Extension Work data at Bagendang Port. This project was carried out by the implementing contractor PT. WijayaKarya (Persero) Tbk. This data we get in the form of planning drawings data from PT Pelabuhan Indonesia III (Persero) as the owner of the job.

In the Building Information Modeling Extension the Multipurpose Pier modeling uses the main software Aecosim with the supporting software Autocad 2013 to process the planning drawing.

\section{Modeling of Pile Structures.}

From the calculation of the structure of the type of spun pile pile with a diameter of $60 \mathrm{~cm} \mathrm{~A} 3$ type the length of the pile is $42 \mathrm{~m}$. Furthermore, this pile data is modeled in the Aecosim Application.

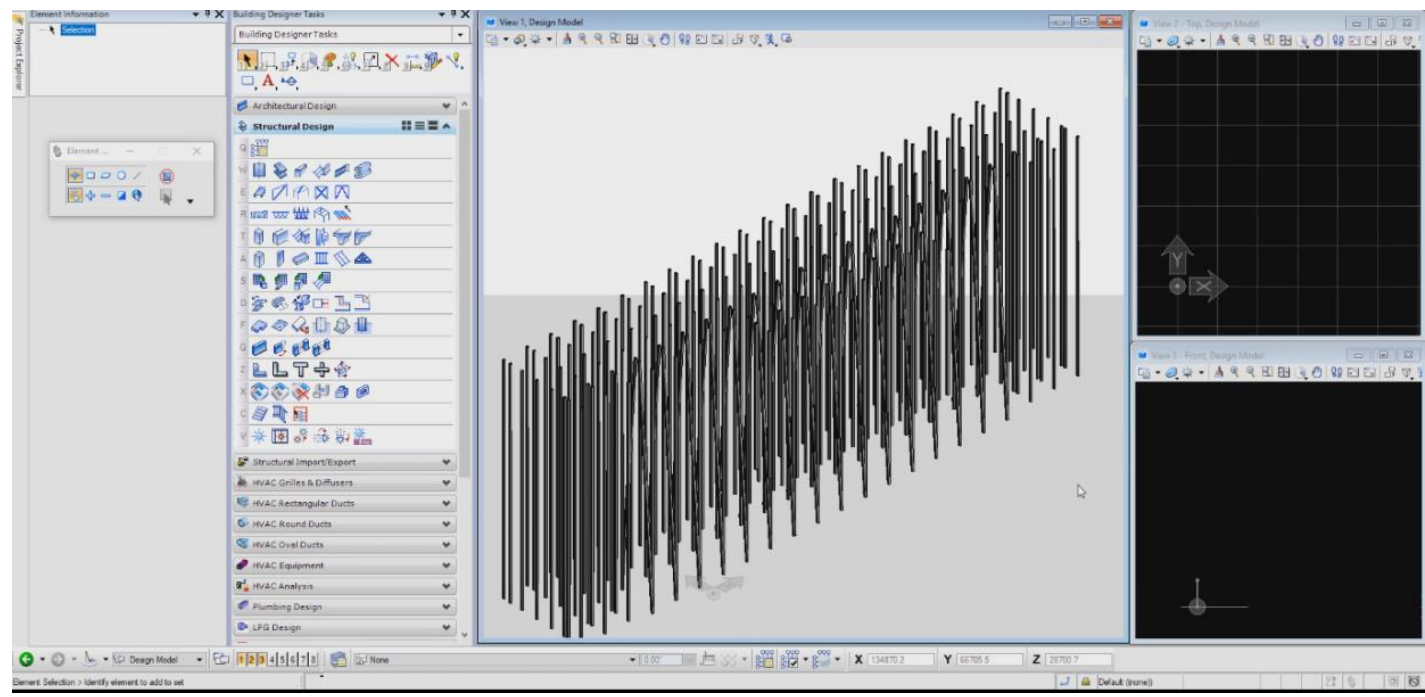

Figure 3 Results of Pier Piles

\section{Pile Cap modeling}

Pile cap is a unifying structure and load bearing from piles, beams and plates. The function of this pilecap is to hold punching shears from the pole (due to the reaction force of the load above the dock). The next step is to model the structure of the pile cap in the top view drawings first. 


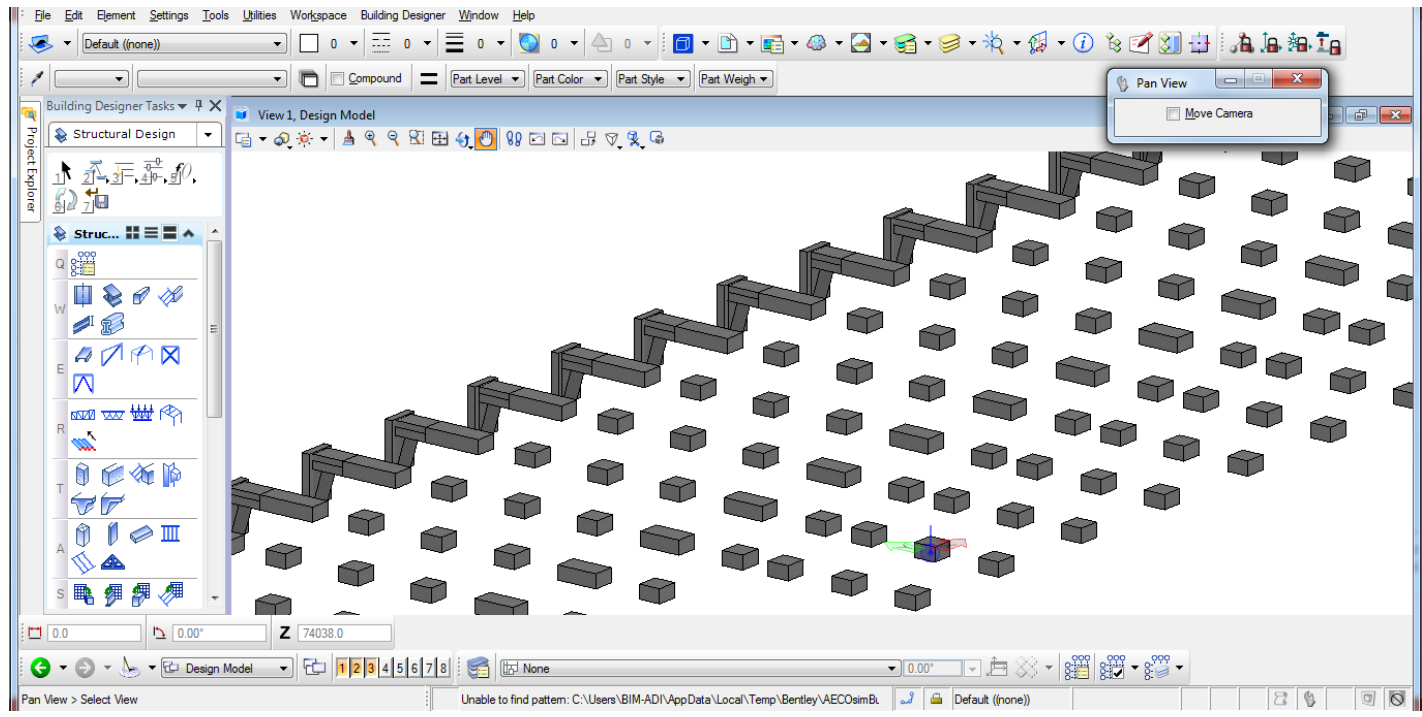

Figure 43D Pile Cap Structure

\section{Beam Modeling}

Beams are part of the structure used as plate holders and pile binders. The function of the pier is to channel the load from the plate to the pilecap, and from the pilecap to the stake.

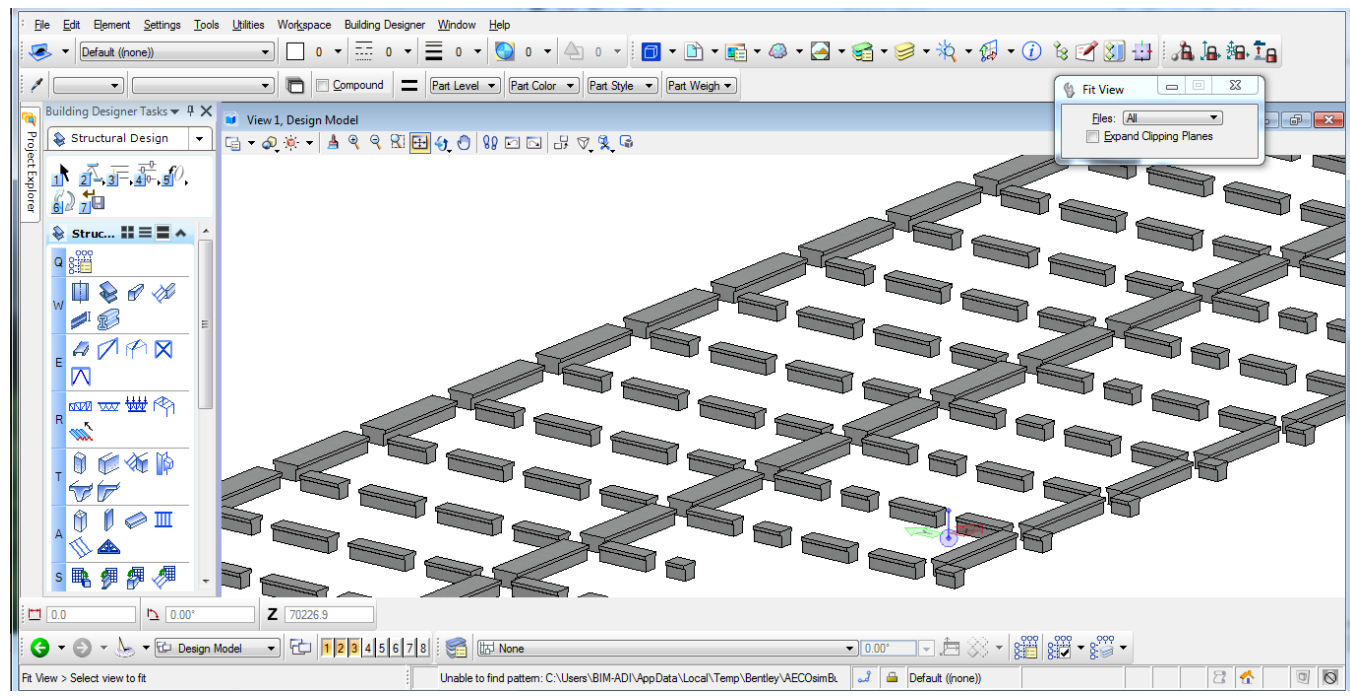

Figure 53D beam modeling

\section{Pier Plate Modeling}

The floor plate is part of the pier element which functions as a place for the Pier's operational activities. Planning of slab elements is no less important than beam planning, pilecap, and pile. Floor plates that are not well planned can cause deflection and vibration when there is a load acting on the plate. 


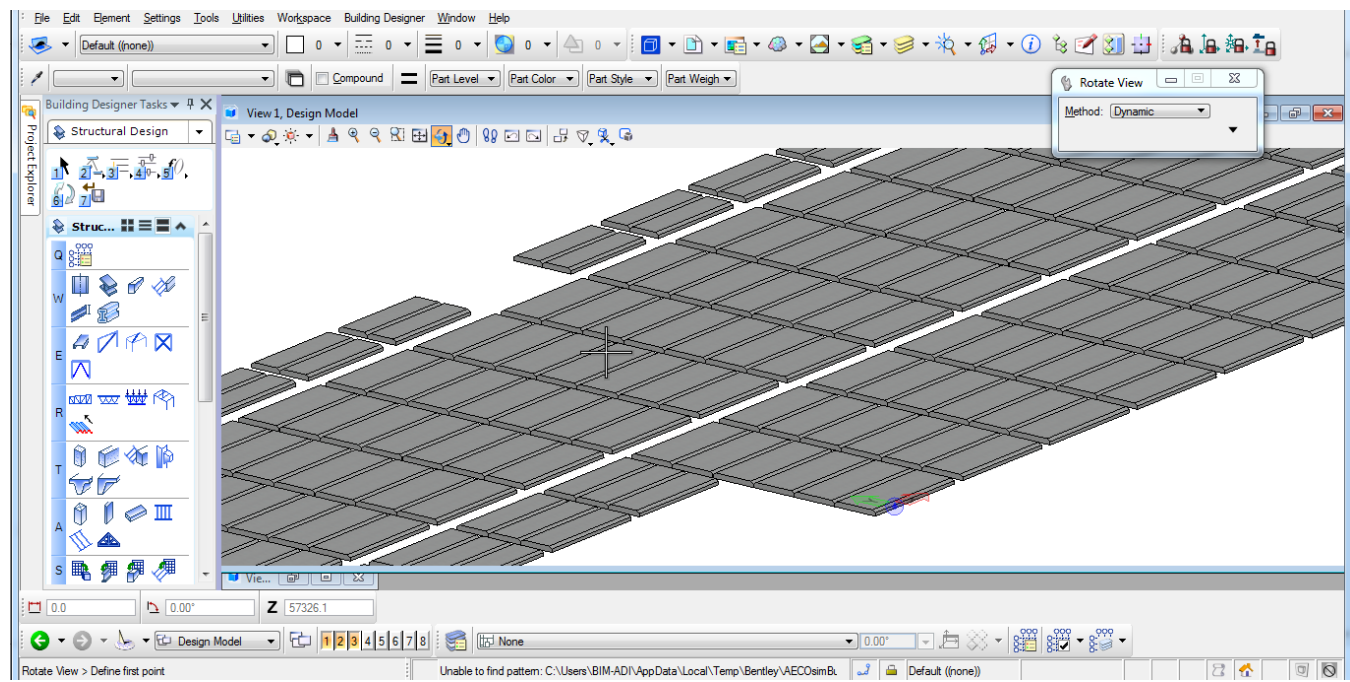

Figure 63D Pier Plates

\section{Modeling the Wharf Overall}

This Aecosim software has its own advantages compared to similar software, namely small files and can be separated from the master file. As an example of a file between the structure of a pile cap, piles, beams and independently separated floor plates that can be merged into one master file. This has the advantage that the aecosim file is not too heavy. The following are the final results of the BIM modeling on the Multipurpose Pier Extension Structure at Bagendang Port.

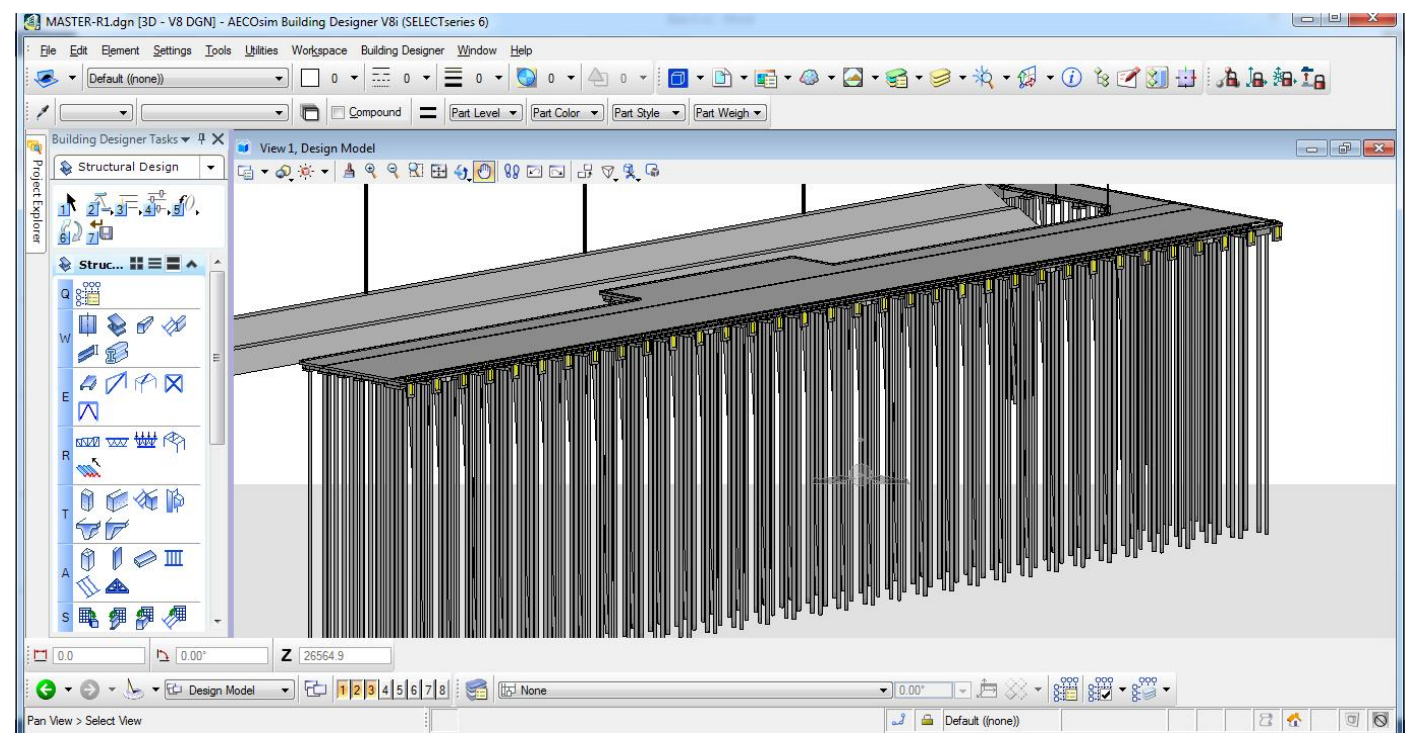

Figure 73D Bagendang Multipurpose Pier 


\section{Reality Modeling Multipurpose Pier Bagendang}

Model the existing environmental conditions using a drone as a tool. In this process the software used is Context Capture. This software functions as a reality modeling in describing the condition of the existing dock

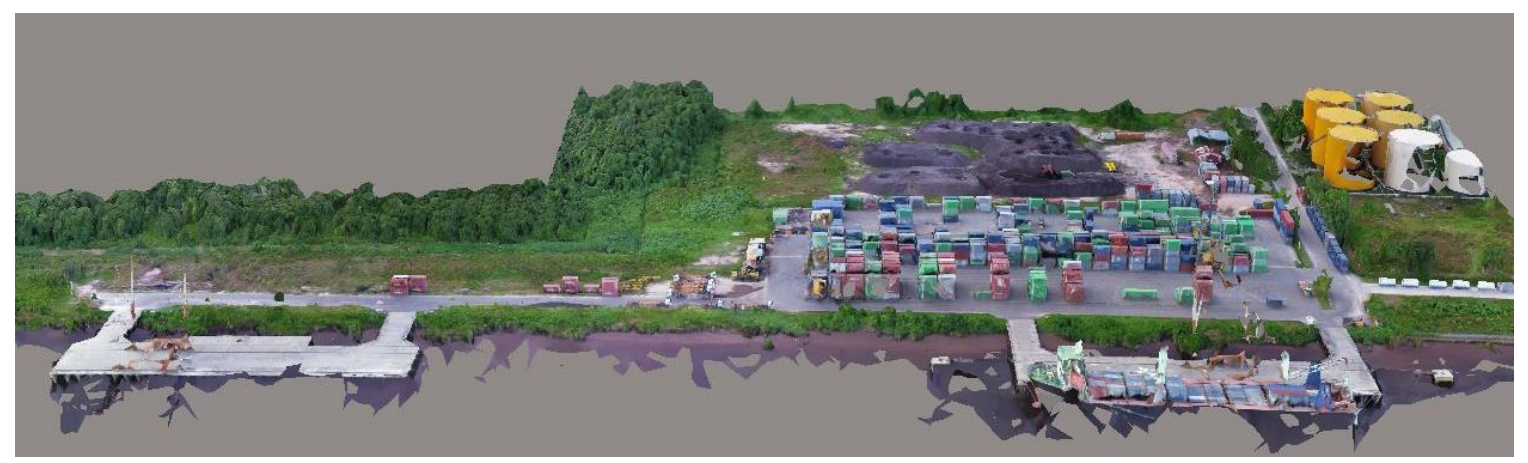

Figure 8Reality Modeling Multipurpose Pier Bagendang

\section{Conclusion}

At the end of the BIM modeling Extension of the Multipurpose Pier in Bagendang Port which the author has carried out. The author can conclude that the Bentley Aecosim Program is capable of displaying BIM modeling both in 2 dimensions and 3 dimensions, so that later it can provide an overview during the process of carrying out the work.

\section{Suggestion}

From the conclusions that we took, there are suggestions to be used as a reference for further research, for the modeling process using Aecosim Building Information Modeling Software should use a high specification computer or laptop with a minimum processor equivalent to Intel pentium i5 or i7.

\section{REFERENCES}

Reinhardt.

2009.

BIM

Authoring

Tools.

https://www.researchgate.net/publication/253058808_Review of Building_Information_Modelin g_BIM_Software Packages_Based on_Assets_Managementdiambilpada 19 November 2018 11:15:35 GMT

BIM Handbook: A Guide to Building Information Modeling For Owners, Managers, Designers, Engineers, andContractors. Kanada: John Wiley \& Sons

Rahayu, R. G. 2015. Analisis Kinerja Waktu dan Pemodelan 3D menggunakan SoftwareTekla Structures17 Pada Proyek Pabrik Astra Honda Motor, Cikampek. Skripsi.

Amir,Faishol. 2017. Studi Desain Pekerjaan Struktur Pembangunan Gedung P1 \& P2 Universitas Kristen Petra Surabaya Berbasis Teknologi Building Information Modeling (Bim), Surabaya. TugasAkhir.

Ramadiaprani, R. 2012. Aplikasi Building Information Modeling (BIM) Menggunakan Software Tekla Structures 17 PadaKonstruksiGedungKuliahTigaLantaiFahutan IPB, Bogor. Skripsi.

Saputri, F. 2012. Penerapan Building Information Modeling (BIM) pada Pembangunan StrukturGedungPerpustakaan IPB menggunakan Software Tekla Structures 17, Bogor. Skripsi.

Dipohusodo, Istimawan.1996. Manajemen Proyek \& Konstruksi - Jilid 1. Yogjakarta : Kanisius (Anggota IKAPI).

Ervianto, W. 2005. Manajemen Proyek Konstruksi. Yogyakarta: CV. Andi Offset.

Kerzner, H. 2001. Project Management, A Systems Approach to Planning, Scheduling and Controlling. New Jersey: John Wiley and Sons, Inc.

Soeharto, Iman. 1999. Manajemen Proyek Dari Konseptual Sampai Operasional. Jakarta: Erlangga. 
Rayendra, Bimo W. Soemardi, 2014. StudiAplikasiTeknologi Building Information Modeling untukPrakonstruksi. Simposium Nasional RAPI XIII-2014 FakultasTeknikUniversitasMuhamadiyah Solo.

Triatmojo, Bambang. 2010. PerencanaanPelabuhan. Yogyakarta: Betta Offset. 